\title{
Conflicts over Natural Resource Scarcity in the Aquatic Ecosystem of the Lake Chilwa
}

\author{
Joseph Nagoli ${ }^{1,2, *}$, Wapulumuka Mulwafu ${ }^{3}$, Erik Green ${ }^{4}$, Patrick Likongwe $^{2}$, Linley Chiwona-Karltun ${ }^{1}$ \\ ${ }^{1}$ Department of Urban and Rural Development, Swedish University of Agricultural Sciences, Sweden \\ ${ }^{2}$ WorldFish, Malawi \\ ${ }^{3}$ Chancellor College, University of Malawi, Malawi \\ ${ }^{4}$ Department of Economic History, Lund University, Sweden
}

Copyright $\bigcirc 2016$ by authors, all rights reserved. Authors agree that this article remains permanently open access under the terms of the Creative Commons Attribution License 4.0 International License

\begin{abstract}
This paper examines the linkage between resource scarcity and conflict during the 2012 Lake Chilwa water level recession. Ecosystem degradation and resource scarcity negatively affect many poor people dependent on aquatic systems such as river floodplains and wetlands. The need to identify and implement innovative measures to manage the scarce resources in these systems has sometimes resulted in conflicts among the various resource users such as fishers, farmers and political groups. However, the direct causal links between resource scarcity and conflict are contested and the evidence base is weak. Using empirical evidence from focus group discussions and in-depth interviews conducted at Chisi Island of Lake Chilwa as a case study, we define the governance groups (vertical and horizontal) and the direct causal links between environmental scarcity and conflict during the 2012 lake recession. We argue that the actual risk of increasing conflicts caused by resource scarcity will depend on the level of vulnerability of populations, ecosystems, economies and institutions in the context of authority, legitimacy and capacities to effectively manage resource scarcity.
\end{abstract}

Keywords Resource Scarcity, Conflict, Ecosystem, Governance, Lake Chilwa

\section{Introduction}

The debate on conflict and resource scarcity has been highly contested. For some analysts, the degradation of the environment was a key explanatory factor of conflict $[1,2]$. These analysts argue that resource scarcity as a result of environmental degradation is portrayed to further drive conflict and act as a threat multiplier of violent conflict, particularly in fragile areas where governance is weak $[3,4$, 5]. Other analysts have recognized that while resource scarcity leads to conflict, conflict mainly leads to resource scarcity through habitat destruction, over-exploitation of natural resources, pollution and the breakdown of environmental programs [6]. Often it is not an absolute scarcity that prevails in conflict, but a resource distribution and mechanisms of access and control. Some natural resources (e.g. global freshwater resources) are not (yet) scarce, but their unequal distribution at different scales provides multiple sources of tension [7]. Sen [8] for example, argues that starvation is sometimes characterized by some people not having access to food and not necessarily a characteristic of there not being enough food to eat. There have also been conflicts recorded between communities surrounding protected areas (parks and forest reserves) and government enforcement staff in Malawi [9]. These conflicts were a result of governments' interest in protecting natural resources through limiting people's access to natural resources inside the protected areas. Resources in this case become scarce to powerless groups. Mehta [10] argues that scarcity of resources has at times been constructed as a "metanarrative" to justify controversial schemes such as large dams, which may result in conflicts.

The linkage between resource scarcity and conflict is therefore not linear. Conflicts over natural resources involve multiple social agents and occur at varying geographical scales. While it is possible to identify particular instances in which scarcity and conflict may be correlated, the deeper question is how the two are linked, and the specific transmission mechanisms through which scarcity can lead to conflict or vice versa. This paper therefore examines the linkage between resource scarcity and social conflict displayed by different social groups (fishers, farmers and political groups) in maintaining livelihoods at Chisi Island of Lake Chilwa during the 2012 water recession. The term conflict in this paper is broadly defined as a struggle, or the clashing of opposing principles or interests. Resource-related conflicts can be both a struggle to gain access to resources, or a result of the use of them [11]. Power struggles exist between and within social groups as they pursue their own 
interests reflecting the human need for vital resources. The concept of resource scarcity in and around the Lake Chilwa basin describes a situation where the ecosystem supply of renewable resources such as water, fish, vegetation and other aquatic resources were not sufficient to meet the demand.

The connection between resource scarcity and conflicts in the lake Chilwa basin is conceptualized by Figure 1 below. The figure shows the interconnectedness of the natural resources scarcity as a result of water recession to conflicts that escalates livelihoods vulnerabilities. The interaction of coping strategies by different actors to vulnerabilities and governance systems results in conflicts exhibited at two levels: within the governance arrangements and within the coping strategies themselves represented by (a) and (b) respectively. However the responses to dealing with resource scarcity and livelihoods vulnerabilities are structured and managed differently as shown by the dotted and continuous lines between 'scarcity' and 'Natural Resources management (NRM) strategies' and between 'vulnerabilities' and 'NRM strategies' respectively. In the next section, we analyses the major conflicts in the two categories.

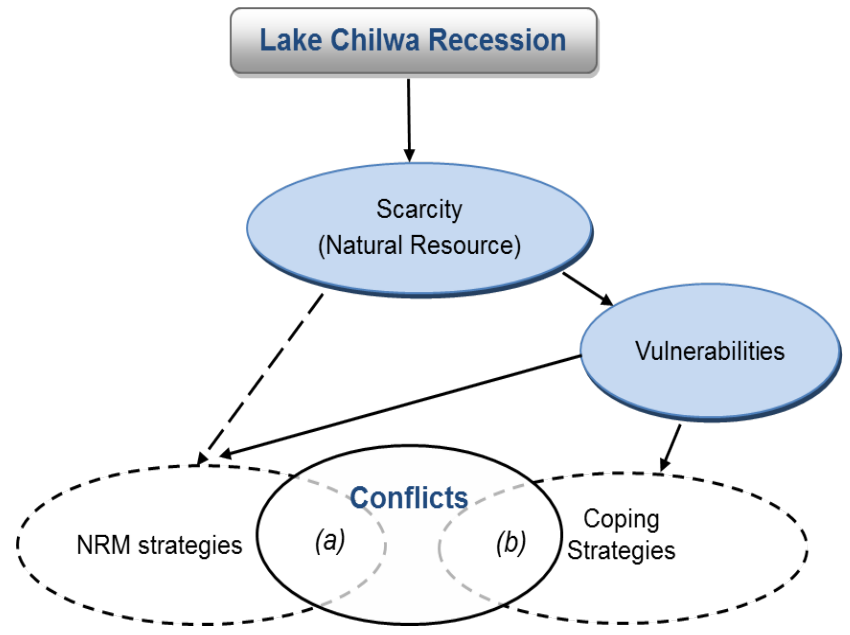

Figure 1. Conceptual framework of the conflict-resource scarcity relationship during the 2012 water recession on the Chisi Island.

\section{Materials and Methods}

In understanding the vertical and horizontal linkages between environmental scarcity and conflict during the 2012 lake recession, the study answered the following questions: Who are the main actors in conflict over limited resources? What are their interests, goals, capacities and relationships? The study targeted the most important users of the aquatic ecosystem: fisher folks, water users, farmers, and local resource governance institutions such as Beach Village Committees (BVC), Village Natural Resources Management Committees (VNRMC) and Bird Hunters Committees (BHC). The study was conducted from July to December 2012.
This study was conducted at Chisi Island of Lake Chilwa. The choice for Chisi was not arbitrary, but ideal for understanding the linkages between resource scarcity and conflict. Chisi Island has an area of about 21 square kilometers $\left(\mathrm{km}^{2}\right)$ and the total population in 2008 was roughly 3000 people. However, the island hosts many migrants who come to trade fish. During peak fishing periods, the population can swell to over 10000 people. In 2008, population density had grown from 164 people per $\mathrm{km}^{2}$ in 1998 to 321 people per $\mathrm{km}^{2}$ registering an increase of about $30 \%$ from that of 1998 [12]. This population density is in contrast to the national average of Malawi of 139 per $\mathrm{km}^{2}$ and that of the southern region of Malawi, where the Lake Chilwa is located, is 184 per $\mathrm{km}^{2}$.

Lake Chilwa has had twelve serious recorded water level recessions in the last 135 years $(1879,1900,1914-15,1922$, 1931-32, -1934, 1954, 1960-61, 1967, 1973, 1995 and 2012). The frequent recessions of Lake Chilwa are explained by the lake's depth and closed nature. The lake only retains water and has no visible surface outflow. In normal years the lake has averaged depths ranging between 1.5 and 2.5 meters. Its catchment is wide and trans-boundary in nature between Malawi (68\%) and Mozambique (32\%). It has been estimated by Rebelo et al. [13] that approximately $60 \%$ of the water in the wetland originates from direct rainfall, with $40 \%$ originating as flows from the surrounding catchment. The highlands receive from $1000 \mathrm{~mm}-1600 \mathrm{~mm}$ of rainfall a year while the plains receive only $800-900 \mathrm{~mm}$. In years of heavy rainfall, flooding is not uncommon. As a result, the open water surface area may contract and expand several times in years of extreme high or low rainfall, contributing to variation in size and salinity [14]. For example, a 2011 satellite image of the Lake Chilwa basin showed that the lake had a total area of 1819 square kilometers $\left(\mathrm{km}^{2}\right)$ comprising three distinct components: open water $\left(828 \mathrm{~km}^{2}\right)$, seasonal open water $\left(303 \mathrm{~km}^{2}\right)$ and seasonally inundated marsh/grassland floodplain $\left(688 \mathrm{~km}^{2}\right)$, in contrast to a recorded total area of about $8350 \mathrm{~km}^{2}$ which comprised of $1750 \mathrm{~km}^{2}$ of open water in 2010 [13]. The seasonal open water area consists of mud and macrophytes and is flooded in the wet season and dries up during the dry season. The marsh floodplain forms a belt around the open water. Temperatures in the basin vary with altitude and range from lows of $10^{\circ} \mathrm{C}$ to highs of $30^{\circ} \mathrm{C}$.

The most recent recession of 2012 was first predicted by fishermen in May 2012. Ecosystem monitoring of meteorological data and river and lake levels by the Lake Chilwa Climate Change Adaptation Program (LCBCCAP) confirmed the fishermen's predictions when the lake water level had receded by $25 \%$. LCBCCAP analyzed the data collected for three years (2010-2012) from the three main monitoring stations of Mposa in the north, Kachulu at the center and Swang'oma in the south (Figure 2). At the north end of the lake at Namanja, the water had completely dried up by June 2012. At the lowest point, the water surface area for Lake Chilwa shrunk by more than $80 \%$. The lake refilled soon after the rainfall season in January 2013. 


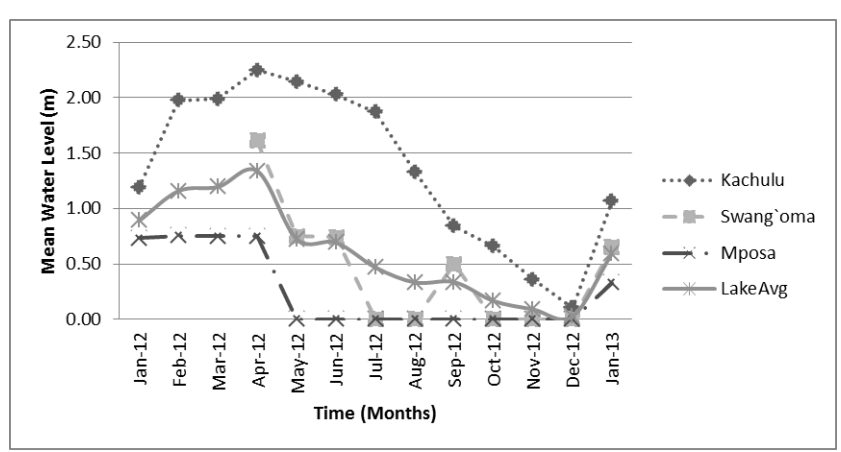

Source: Lake Chilwa Basin Climate Change Adaptation Program

Figure 2. Mean monthly water levels from three gauging stations in the Lake Chilwa

The 2012 water recession also coincided with an economic meltdown in Malawi. Following recommendations from the International Monetary Fund (IMF), the local currency, Malawi Kwacha (MWK), was devalued by about $50 \%$ in May, 2012. After the devaluation, the MWK continued to be unstable against the international trading currency (US\$) and kept depreciating until April 2013. Inflation rose to $34 \%$ attributed mainly to high prices of food. The economic collapse resulted in the closure or down-scaling of industrial production, which is the largest employer after the agricultural sector. The combination of economic pressures and population growth exerted stress on natural resources during the recession and resulted in short-term and unsustainable coping strategies.

The study was done in two phases: The first phase used an institutional analysis method by applying participatory approaches (Focus Group Discussions and in-depth interviews). The Focus Group Discussions (FGD) included fishers, fish processors, traders, transporters, farmers, natural resource governance leaders, and traditional leaders and were conducted in each of the 13 villages of Chisi Island. All groups consisted of local Chisi residents and migrants comprising of women, men and youths. To facilitate openness, females and males formed separate groups. The FGDs used participatory tools namely: resource mapping, institutional analysis, cause-effect analysis and seasonal calendars.

Following general community consent and consent from the Traditional Authority Mkumbira, 25 in-depth interviews that included two women were conducted involving fisher folks, farmers, natural resource governance leaders, and traditional leaders for deeper understanding of the social conflicts. The number of interviewees was reached heuristically, i.e., the decision to stop adding respondents was taken when no new information was being gathered from the interviewees [15]. The choice of interviewees was based on the interviewees' relevance to the conceptual questions on conflicts rather than their representativeness.

The second phase employed ethnographic field study on Chisi Island. The study involved participant observation that was done by residing within the community at Chisi Island from August to December 2012. The observations were aimed at understanding social networks, customs, governance issues and interpretations of social actions [16]. The ethnographic study included the understanding of global discourses on environmental scarcity and how the discourses are translated into local ideas to prevent or manage conflict. There was no rigid separation between data collection and analysis in this process, and the procedure was an iterative cycle of data collection and analysis of content and themes, with the intention that the results of the analysis would guide the subsequent collection of data $[15,17]$.

\section{Results and Discussion}

\subsection{The Lake Chilwa Basin Ecosystem Services}

The Lake Chilwa ecosystem provides important ecological functions to the households of the basin. These functions bring both physical and non-physical benefits in the form of provisioning services such as food, water, and construction materials; regulating services in the form of water and air purification and climate regulation; cultural services in the form of worshiping shrines; and supporting services such as soil formation, photosynthesis, and nutrient cycling. The Lake Chilwa ecosystem provides services valued at over US\$21 million per annum [18]. According to Schuijt, fishing is the main occupation in the basin and contributes about US $\$ 18$ million in normal productions. Agriculture in the Lake Chilwa basin is valued at US\$ 1.2 million, the lake grasslands is about US\$ 640,000 , surface water at US\$ 400,000 and bird hunting at US\$215,000. Lake water is also used for domestic purposes and irrigation. There are two large rice irrigation schemes (Domasi and Likangala) and many other small-scale irrigation projects in the Chilwa basin. The vegetation is used for thatching houses including construction of temporary homes on both upland and floating lake houses locally known as zimbowela. Ecologically, the vegetation does not only provide feeding and breeding for fish, but it also acts as a sieve and reduces water turbidity [19].

Lake Chilwa is regarded as one of the most productive lakes in the world with a biomass productivity of 159 tones/ha per year. The high productivity is driven by the growth of extensive typha swamps, estimated to be 25 to 30 tons per hectare per year $[20,21]$. Lake Chilwa and its wetland are also a home to over 160 species of birds, including 37 migratory species [22]. The rich natural resource biodiversity (Table 1) is an important source of livelihoods to over $85 \%$ of the households living in the basin [23]. In normal years, the Lake Chilwa basin supports the livelihoods of more than 1.2 million people [12]. In times of crisis the resources from Lake Chilwa basin acts as a safety net for the poor people from most parts of Southern Region of Malawi. 
Table 1. The main natural resources in the Lake Chilwa Wetland

\begin{tabular}{|c|c|c|c|}
\hline Main Category & Name & Scientific name & Local name \\
\hline \multirow{3}{*}{ Fisheries } & Tilapia & O. shiranus chilwae & Makumba \\
\hline & Barbus & Barbus paludinosus & Matemba \\
\hline & Catfish & Clarius gariepinus & Mlamba \\
\hline \multirow{10}{*}{ Vegetation } & False bulrush & Typha domingensis & Njedza \\
\hline & Flotters & Aeschomene pfundi & Mabungwa \\
\hline & Sedge & Cyperus articuulatus & Mlulu \\
\hline & Typha & Typha spp & Mabawe \\
\hline & Hippo grass & Vossia cuspidate & Duvi \\
\hline & Reeds & Phragmites mauritianus & Bango \\
\hline & Soft -shelled turtle & Cyloderma frenatum & Nombo \\
\hline & Nile cabbage & Pistia stratiotes & Chipiri \\
\hline & Hornwort & Ceratophyllum demersum & Kakombwe \\
\hline & Water hyacinth & Eichornia crassipes & Namasupuni \\
\hline \multirow{3}{*}{ Animals and reptiles } & Hippos & Hippopotamus amphibious & Mvuwu \\
\hline & Crocodile & Crocodylus niloticus & Ng'ona \\
\hline & Snakes (lowland swamp viper) & Antheris superciliaris & Njoka \\
\hline \multirow{15}{*}{ Birds - waterfowl } & Fulvous whistling ducks & Dendrocygna bicolor & Chipiyo \\
\hline & White-faced whistling ducks & Dendrocygna viduata & Chipiyo \\
\hline & Reed cormorant & Phalacrocorax africanus & Mphipi \\
\hline & Lesser moorhens & Gallinula angulata & Nthutuwiri \\
\hline & Lesser gallinule & Porphyrio porphyrio & Nadititi \\
\hline & Allen's Gallinule & Porphyrio alleni & Nadititi \\
\hline & Spur-winged goose & Plectropterus gambensis & Sekhwe \\
\hline & Pink-backed pelican & Pelecanus rufescens & Chikovili/Vuo \\
\hline & Great white pelican & Pelecanus anocratalus & Chikovili/Vuo \\
\hline & Little egret & Egretta garzetta & Kakowa \\
\hline & Cattle egret & Bubulcus ibis & Kakowa \\
\hline & Yellow billed egret & Egretta intermedia & Kakowa \\
\hline & Grey-headed gulls & Larus cirrocephalus & Nkhalakata \\
\hline & Black Crake & Amaurornis flavirostris & Namalindi \\
\hline & Glossy Ibis & Plegadis falcinellus & Njinjinji \\
\hline
\end{tabular}

Source: Updated from the Lake Chilwa Climate Change Adaptation Program

\subsection{Natural Resources Governance Arrangements}

Natural resource governance has moved from traditional management to co-management in the last century, as described in Table 2. Co-management involves the mobilization of communities into representative user committees to become voluntary natural resources protection officers.

Table 2. Historical trends in fisheries governance systems in Malawi

\begin{tabular}{|l|l|l|}
\hline \multicolumn{1}{|c|}{ Period } & \multicolumn{1}{|c|}{ Governance System } & \multicolumn{1}{c|}{ Main Features } \\
\hline Early $20^{\text {th }}$ Century & Traditional Fisheries Management & $\begin{array}{l}\text { Systems of authority aligned with local chiefdoms } \\
\text { Native Authorities (NA) now called Traditional Authorities (TA) as } \\
\text { custodians of natural resources }\end{array}$ \\
\hline 1930 & Centralized Fisheries Management & $\begin{array}{l}\text { Introduced in 1930 by adding Section 3: Fishing Rules MP.437 to the Game } \\
\text { Ordinance } \\
\text { Centered at the national level (government), with lower degrees or none at all } \\
\text { of resource user participation. } \\
\text { Management based on the theories of Maximum Sustainable Yield (MSY). }\end{array}$ \\
\hline 1997 & $\begin{array}{l}\text { Introduced through the Fisheries Conservation and Management Act of } \\
1997 \\
\text { Brings together the government and the user communities to manage the } \\
\text { same resources }\end{array}$ \\
\hline
\end{tabular}

Source: own analysis from historical records 
The study found four co-management structures present in the Chilwa basin and included: BVCs for fisheries, VNRMCs for forestry, BHCs for water-fowl populations, and Water Users Associations (WUA) for water in the irrigation schemes. Co-management in fisheries was introduced by the Department of Fisheries in response to popular advocacy for community participation and decentralized natural resource management [24]. Under these conditions, the BVCs were legally vested with powers to enforce fishery regulations, including closed seasons, gear and mesh restrictions, and licensing of gear. The BVCs under co-management authorized both small-scale and commercial fishers to land on their beach and maintain beach registers containing information on registered fishing vessels, gear owners, and fish workers [25]. BVCs restricted the use of undersized meshes. The use of gillnets with mesh sizes less than 2.75 inches $(7 \mathrm{~cm})$ and seine nets of less than $1 \mathrm{~cm}$ were prohibited in Lake Chilwa. The BVCs also implemented and monitored a 'closed season' from commercial fishing every fishing calendar from November to February to allow fish to breed and stocks to recover.

Although the shift from traditional management to co-management has been perceived as a move towards putting "community in conservation" [26], its practical implementation in the Lake Chilwa was more complex than the dynamic shift of responsibility and authority from the state to the inclusiveness of communities in conservation. There were conflicts within and outside the co-management arrangement. It was unanimously agreed during the FGDs that conflicts increased during the last decades, due to the breakdown of traditional mechanisms that governed natural resource and managed conflicts. The establishment of co-management governance institutions was said to have created a parallel leadership structure that competed with traditional leadership [25, 27, 28]. Kayambazinthu and Kagelheide [29] also noted that institutions in co-management provide the opportunity for powerful actors to exclude others from access and to privatize certain resources or user rights. To understand the background to the conflicts that happened during the 2012 lake recession, it is necessary to investigate the traditional governance history and political structures that existed for managing the resources of the Lake Chilwa basin. Local communities on Chisi Island had long-established norms to preserve fish stocks during previous recessions. These norms were based on historical knowledge of the lake ecosystem and its periodic fluctuations in water levels. Knowledge of the importance of vegetation in the productivity of the lake was well entrenched in the local population, and has existed for generations [25]. Some of the old local management traditions included:

Conservation of sacred sites where cutting of Typha (njedza and mabawe) and fishing was restricted.

FGDs and key informants reported that customary leaders under traditional management restricted fishing in areas covered by Typha (mabawe). People surrounding the lake conserved mabawe because they are coated with algae, which is food for fish, and are therefore important fish breeding sites. Additionally, mabawe physically shield fishermen from rough waves in times of strong winds on the lake. Apart from protecting vegetation on the lake, no fishing was allowed at Chaone and Chidyamphiri Islands for fear of displeasing spirits. Key informants reported that the small island of Chaone was visited only after the traditional leaders, led by Village Headmen Khumali, Sonkho and Tchuka went to offer sacrifices to their ancestors. Fishing around Chidyamphiri Island was only allowed during famine and had to be sanctioned by the traditional leaders. All fishermen who did not abide by this rule were banned from fishing and sometimes evicted from the fishing villages. The importance of Chidyamphiri Island for traditional religion was confirmed by the colonial game warden when he wrote the colonial Chief Secretary in Zomba in 1930, asking him to declare Chidyamphiri Island a protected game reserve for its python population and 'rain spirit' shrines [30]. It was also reported that in past decades chiefs restricted fishermen from using poisonous herbs such as Tephrosia vogelli (katupe or ombwe) and Eurphorbia tirucalli (nkhadze) and anyone found using these herbs to fish was banned from fishing. There was a common belief that fish caught from these herbs did not taste good. Another taboo related to resource management as reported by Kalanda-Sabola et al. [31] was 'No fishing when a wife was pregnant'. This practice is reported by the authors as reducing the number of men going fishing and thereby reducing fishing effort.

Group Village Headman (GVH) Tchuka said that although the traditional management rules were made and enforced by the village headmen, few cases of violation occurred because every user understood the importance of preserving fishing as a livelihood and as a cultural identity. GVH Tchuka may have said this to underpin the importance of traditional leaders in natural resource management. In recent times, the hybridization of neoliberal and modern institutions has brought more challenges than opportunities in natural resource management [28]. Current local governance arrangements under decentralized arrangements require a District Executive Committee (DEC) at the district level, followed by an Area Development Committees (ADC) that takes care of the Traditional Authority's (TA) jurisdiction. The DEC and ADC are responsible for development planning, prioritization, implementation and oversight at district and TA levels respectively. All villages under one GVH form Village Development Committees (VDC) that report to the ADC. At the village level people form community-based organizations (CBO) such as natural resource governance committees. The $\mathrm{CBO}$, VDC, ADC and DEC sequentially develop, implement plans and enforce compliance to by-laws for each resource use in that hierarchical order.

\section{Use of illegal gears}

Interviews with key informants reported that in the past fishermen on Lake Chilwa used traditional selective gears such as traps (mono), spears (momba), long lines and gill 
nets. Chilivumbo [32] also reported the use of other traditional gears in lake Chilwa such as long line hooks (khuleya); grass scoops (kwakwaza wa rumba); and scoop nets (kwakwaza wa mng'ono). Large seine nets were forbidden from use on the lake because they caught more fish and leaders were cautious of depleting the fish stock quickly. It was discovered during the FGDs that each type of traditional fishing gear was designed from an intimate knowledge of sub-lacustrine topography and habitat of the targeted fish species.

The use of small mesh sized nets for catching fish increased during the 2012 recession as normal mesh sizes were inefficient in catching more fish. The undersized nets, mostly mosquito nets, caught fish of all sizes. The mosquito nets were obtained from government health centers under the malaria prevention program, and had been given free to pregnant mothers and under-five children to protect them from mosquito bites that cause malaria. Female focus groups reported that corruption was the main driver to the escalating use of illegal gears. They reported that fishers (mostly men) bought their access to fish using illegal gear from government enforcement staff (fisheries department and police). The corrupt practice did not spare local leaders, leading to increased conflicts amongst the leadership at various levels. Tensions also emerged among members of the chief's lineage as to who was legitimately able to transact on behalf of the family. Legitimacy and authority in this case are the normative status conferred by a governed people upon their governance institutions. When one member of the chief's family was bribed, other members followed the briber, claiming that the money was paid to the wrong person who was not a legitimate member eligible of representing the family. In this way the fishermen were forced to pay additional money to whoever claimed to be a member of the ruling group. Corruption in this instance was a bargaining act extended to a negotiation over rules and regulations for personal gains. Due to bribery, confiscated illegal gears were often seen back on the lake after a few days, which led to further conflicts among fishermen on the lake.

\subsection{Conflicts and Scarcity during the 2012 Lake Chilwa Recession}

Conflicts on natural resources governance and policy

Conflict has a strong bearing on institutions and governance, which in turn affects power and control over the management of natural resources [33]. Governance in this case characterizes the way in which various state and non-state actors interact horizontally across spatial borders as well as vertically across administrative scales, and how these interactions are regulated by formal and informal institutions [33]. The relationship between governance regimes, such as vertical integration or the degree of centralization (such as sectoral fragmentation and regulation) was found to be unestablished at Chisi Island. It was concluded during FGDs that many of the government departments work through local committees. However, the working relationship between departments was disjointed and there was little coherency in the delivery of the messages by various sectors. The Lake Chilwa basin lacked a formal authority to coordinate the governance process, such that management activities at different levels were implemented in isolation. It was not uncommon therefore to find one community member sitting on more than three different committees in the same week. For example, Nambewe (not her real name) from Kotamo Village on Chisi Island was the treasurer of a village savings and lending group, secretary of VNRM, and executive committee member of BVC. This weak governance system negatively affected the effectiveness of natural resource management in the area. Figure 3 shows the various organizations that worked in the communities of the Lake Chilwa basin.

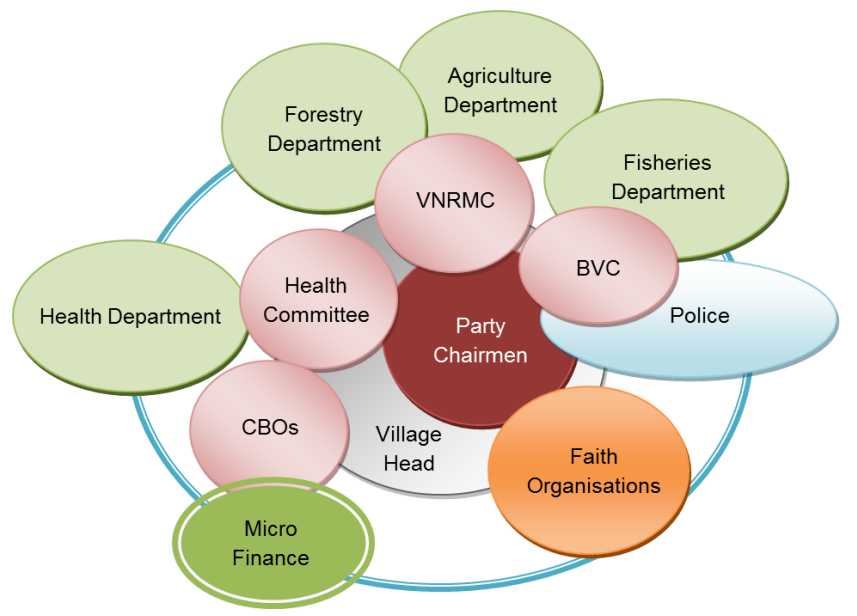

Source: Study data on institutional analysis

Figure 3. The network of governance institutions in the Lake Chilwa basin

Figure 3 shows that the organizations present in Lake Chilwa basin operate on two levels: 1) those that were in direct contact with the community such as faith based groups and local resource management groups such as BHC, BVC, VNRMC and WUA. These organizations are represented by the inner grey circle. 2) District administration and national organizations dealing with policy and other social services (represented by the outer blue circle).With so many local institutions, the 2012 water recession brought up the question of which institution had the legitimate power to manage conflicts. For example, fisher folks looked at the $\mathrm{BVC}$ as an institution that had the mandate to manage fishery resources. However, the conflict resolution resulting from fishing was often observed to be handled by local leaders.

On the policy front, there were many legal frameworks affecting the governance of the Lake Chilwa resources during 2012. Some of these included policies on sustainable management of wetlands including birds [34]; the Environment Management Act of 1996 [35] that enabled the development of co-management systems of natural resources; the National Fisheries and Aquaculture Policy of 2001] [36] that aims to ensures sustainable exploitation of 
the fisheries without undermining the environment; the National Water Policy as revised in 2005 [37] that is meant to address all aspects of water including aquatic resource management, development and service delivery; and the Wildlife Policy of 2000 [38] that promotes biodiversity conservation in Malawi. The sheer number of diverse policies affecting resource management in the Lake Chilwa basin makes it uncertain as to which regulatory or policy framework was supreme when dealing with conflicts over natural resources in the Lake Chilwa basin. For example, although fisheries were managed by the Fisheries Department, the vegetation in the lake where fish breed was under the management of the Department of National Parks and Wildlife, while the water itself was under the Water and Irrigation Department. Bits and pieces of the Chilwa resources were therefore managed by different policies, and legal and management frameworks. Chinsinga et al. [39], analyzing a crop diversification initiative in Malawi, also pointed out the conflicting government policies that undermine the potential contribution that development projects make to the livelihoods of Malawians.

Participants from the FGD suggested the harmonization of different natural resource management committees into one institution for all natural resource governance in the Lake Chilwa basin. Furthermore, it was agreed that all policies on management of natural resources should be synchronized by analyzing the roles, authority and legitimacy of different institutions and what this implies for their success in managing new contestation over natural resources. The suggestions from resource users on governance reforms confirm the need to use grassroots experiences to inform macro-level policies.

In addition, Lake Chilwa has a natural resource management plan that was developed in the year 2000 with the objective of enabling local communities to manage and utilize natural resources sustainably. However, the management plan was being implemented by the Wildlife Department and mainly focused on the conservation of birds. In implementing the plan, the Danish Hunters Association established the Bird Hunters Association (BHA) in 2003 to manage bird hunting and to protect bird breeding sanctuaries. However, the BHA was only active in a few selected areas believed to be nesting grounds for the birds. The BHA had formed 18 BHCs and 29 community protected bird breeding sanctuaries. The implementation of this management plan by one sector excluded other important sectors such as fisheries and water from actively implementing the plan. Similarly, this approach did not recognize the importance of a multifaceted and holistic approach in managing natural resources, such that fisher folk had no role in protecting the birds as evidenced by the following extract from BVC members during a FGD at Chisi.

We don't know the roles of Bird Hunters Committee and we were not told that the birds are also protected. We just know that the people from Sombi and
Ngotangota, where this committee is located, are not allowed to kill birds anyhow. But for us, birds are our manna [food] when we don't have fish. (Namakwaila $\mathrm{BVC})$

The main food and income coping strategy of the people at Chisi Island during the recession was bird hunting from protected sites. It was reported by local bird hunters that the average catch per hunter had increased from two birds per week during normal years to over 50 birds a day. This catch magnitude was against the by-laws on sustainable bird hunting established by the BHA. The birds were smoked and sold in Zomba City and other places. Findings from the study showed that prices for both the local and urban markets for each bird increased from MWK 50 (US\$ 0.15) to as high as MWK3000 (US\$ 9), from the period January to December 2012. The most typical birds that people consumed were common moorhen (Gallinula chloripa), locally known as Nkhutuwiri while those preferred by customers in Zomba were whistling ducks (Chipiyo). Bhima [18] estimates that bird hunting increases by $300-500$ percent during times of low water levels because it provides important sources of food and income to vulnerable and marginal communities. Bhima estimates that approximately 460 bird hunters trap 1.2 million birds every year from the Lake Chilwa area.

Conflicts on coping strategies between migrants and local residents during the 2012 Lake Chilwa recession

In 2012, a large population of migrants came from the Nampeya area in the far north of the Lake Chilwa (Nayuchi area in Machinga) to Chisi Island fishing sites. The northern part of the lake is shallower and dries first in any recession. This group of migrants is referred to in this paper as 'Nampeya' to distinguish them from migrant groups that came from other parts of the southern region of Malawi. Migration is a coping mechanism frequently adopted when environmental factors turn harsh. During the 2012 recession, the incentives for migration increased and these incentives were primarily economic. The conflict between migrants and Chisi resident fishers were manifested through tensions over space, sanitation and social structure adjustments. The resident Chisi fishers reported that the Nampeyas were skilled fishers especially in marshy areas. They fished by enclosing the vegetation with a big net of small mesh size (mostly mosquito nets). They then cut all the vegetation using sickles and pangas and 'hunted' all the fish into the net. As indicted earlier, marshy and vegetative sites around Chisi were traditionally protected from fishing because they were regarded as fish sanctuaries and breeding grounds. The resident fishermen led by BVCs therefore organized themselves, confronted the migrants and confiscated the illegal gear and fish from the Nampeyas. The catch from Nampeyas was sold and the money used to support BVC's operations. Physical conflicts subsequently erupted with the Nampeyas fighting back to protect their catch. The Nampeyas retaliated with physical force using the hunting equipment (sickles and pangas). Participants of FGDs 
revealed that in an encounter between the Nampeyas and the locals at Namakwaila fishing site, an altercation erupted where several people were injured and one person died from heavy bleeding. In-depth interviews with the Nampeyas confirmed the fishing practice but contested stating that the conflict was purely based on jealousy by the Chisi fishermen because they were denied fishing in the protected areas by their local leaders. They also indicated that their fishing style was driven by the high demand for fish from the Chisi residents themselves. Analysis from both the Chisi Islanders and the Nampeyas showed that the high demand for fish had made fishing by Nampeyas more lucrative. One Nampeya confirmed that he was able to earn MWK 250,000 (US\$ 714) in sales from one fishing errand by selling the fish at Chisi Island.

There were also conflicts between Lake Chilwa fishers and migrant fishers from Lakes Malawi and Malombe. Migrant fishers from these two lakes used large seine nets of smaller mesh size and caught more fish including juveniles. These migrants were said to travel to Lake Chilwa with their big nets during peak fishing seasons and return when Lake Chilwa water levels drop. The local Lake Chilwa fishermen, by practice do not migrate to lakes Malawi and Malombe because their gear are very simple and cannot withstand the depth and heavy currents of the two lakes $[12,40]$. Additionally, fishing in these two lakes is strongly regulated so that new entrants find it difficult to fish. For example, Mr Makawa, a fisher from Lake Chilwa who acquired large gear and travelled to Lake Malawi during the water recession, faced stiff competition and had to return to Lake Chilwa. In explaining his ordeal, he said:

I went to Lake Malawi to fish but because of intolerance by the authorities [BVC], I have rented (kupinyolitsa) my gear to someone right there. I came back to Kachulu and sold my generator to raise money for reclaiming my gear. (Makawa)

Conflicts over territories have also been reported within Lake Chilwa between Malawian and Mozambican fishers in the Mozambican fishing sites. Malawian fishers migrate to Mozambican territory during seasons when Malawian waters are closed for active fishing [41]. Closed season is only observed in Malawi and not in Mozambique which problematizes the governance of shared water resources especially during scarcities. The conflict over territories in general, and in particular between Chisi fishers and migrants, exemplifies that conflicts over territorial fishing boundaries, such as the management schemes on trans-boundary fisheries based on Exclusive Economic Zones (EEZ) boundaries as prescribed by the United Nations Convention on the Law of the Sea [42], may become challenged during scarcity. Such policies may fuel conflict, as some actors may be denied access because of differences in jurisdictions and territorial rights systems.

Changes in social structure when coping with scarcity

This section presents the social arrangements among different groups as a result of the 2012 scarcity at Chisi based on the narratives of stratification, strain and cultural deviance [43, 44, 45]. Social stratification suggests that people violate the rules and regulations because of the breakdown of social control, while strain narrative views conflict as resulting from the anger that people experience over their inability to achieve legitimate social and economic success. These theories hold that most people share common values and beliefs but the ability to achieve them is differentiated throughout the social structure including gender inequalities [46]. Social structural differences between migrants and Chisi residents during the recession resulted in the former, especially the Nampeyas, being denied accommodation space on the island. However other migrants, expressly fish processors and traders, were allowed accommodation on the island. Subsequently, the Nampeyas constructed zimbowela, which later developed to established lake villages. Eventually other ancillary businesses, such as bars and grocery stores were opened in these villages. The zimbowela communities were independent of the local social arrangements where a village head was in charge of a village including its land. The situation brought up leadership questions on who controls the water space of the lake. It caused conflicts over access through competing claims of rightful authority over the water resources. Additionally, conflicts arose around waste management and general sanitation within the lake villages. Without safe domestic water and other waste disposal structures the villages became a health and sanitation hazard to the dwellers and even the surrounding communities. There was an outbreak of cholera on the mainland during the year which was entirely blamed on the zimbowela villages.

The 2012 resource scarcity was also reported to have had a direct effect on early marriages of young girls and prostitution. Five school girls at Chisi Island were reported to have been married as second wives by the Nampeyas and taken away from local villages without their parents' consent. Nachisale (not her real name), the mother of one of the girls confirmed in her assertion:

They [the Nampeyas] had a lot of money from illegal fishing and were at liberty to propose to any woman whom they wanted. They cheated my daughter who had just started secondary school. My daughter is now married by these Nampeyas and they took her to their villages. (Nachisale)

Male focus groups reported that women violated a traditional gender norm that does not allow women to fish in open waters. Because the water level had gone so low, simple gears such as small mosquito nets and cloth wrappers (zitenje) could easily be used by women, allowing them to fish the open waters of the lake. When this violation was reported to traditional leaders, the women sought support from human rights activists within the villages who justified that women had the right to fish. Issues of human rights challenged traditional rules and thus weakened local leaders' 
authority in protecting tradition and culture. The tensions in social structure showed that the linkages between conflict and scarcity are extremely complex. These conflicts demonstrated the value of understanding local-level drivers of conflict, as opposed to the more typically reported social consequences such as mortality, malnutrition and starvation. While admitting that social tensions were not acting independently and were not coincidental to scarcity, it would be naive to discount that changes in social structure could also happen independent of scarcity. The understanding of this complex relationship is therefore important in finding more equitable management schemes. The recession of Lake Chilwa in 2012 provided a tangible case to evaluate the challenges of resource scarcity and conflict management. The recession specifically demonstrated how resource scarcity is embedded in a shared social and delineated space where complex and unequal relations are established among a wide range of social actors - fisher folks, farmers and governance institutions. The 2012 resource scarcity in Chilwa was also different from previous recessions due to the high population that was dependent on scarce resources.

\section{Conclusions}

Conflicts over natural resources are aggravated by the overlap of many factors such as migration, high levels of inequality, injustice and poor governance. This paper has demonstrated that the extent to which natural resource scarcity threatens livelihoods and results in conflicts under economic pressures depends on the legitimacy and authority of local and government institutions in managing scarcity and governing resource users. Conflicts have the potential to become particularly violent when compounded by insecurity, socio-economic and political stresses. Although factors underlying conflicts are multi-causal and should be considered as such, thoroughly analyzing the linkages between these factors is a basis for understanding the associations between conflict and resource scarcity. The findings have illustrated the most important problem with the environmental resource scarcity-conflict thesis; where political and economic factors are largely ignored in their explanation.

This paper has shown that conflict during times of scarcity on Chisi Island was caused by the socio-ecological dynamics surrounding the Lake Chilwa recession. The combination of scarce resources and external economic pressures lead to conflicting coping strategies, environmentally related conflicts and habitat degradation. Similarly, inequalities in accessing resources, as well as the economic meltdown happening during the same period, promoted lifestyles which were self-destructive. Finally, the sheer volume of diverse policies (local, national, international) affecting the Lake Chilwa basin, highlighted the uncertainties in the governance system of the basin's natural resources. The number of institutions and incidences of governance conflicts are likely to increase in the Lake
Chilwa basin with the continuing introduction of new and disconnected institutions.

\section{Acknowledgements}

This work was supported by the WorldFish as part of a $\mathrm{PhD}$ research project by the corresponding author. Additional data was provided by the Lake Chilwa Climate Change Adaptation Program supported by the Royal Norwegian Embassy in Malawi.

\section{REFERENCES}

[1] T. F. Homer-Dixon. Environmental Scarcities and Violent Conflict: Evidence from Cases. International Security, Vol. 19, No. 1: 5-40, 1994.

[2] V. Percival and T. F. Homer-Dixon. Environmental Scarcity and Violent Conflict: The Case of South Africa. Journal of Peace Research. Special Issue on Environmental Conflict Vol. 35, No. 3: 279-298, 1998.

[3] T. F. Homer-Dixon. The Environment, Scarcity, and Violence, Princeton University Press, Princeton. NJ, 1999.

[4] R. Munang, I. Thiaw, M. Rivington. Ecosystem Management: Tomorrow's Approach to Enhancing Food Security under a Changing Climate. Sustainability Vol. 3, No. 7: 937-954, 2011.

[5] R. Munang, I. Thiaw, K. Alverson, M. Mumba, J. Liu, M. Rivington. Climate change and Ecosystem-based Adaptation: a new pragmatic approach to buffering climate change impacts. Current Opinion in Environmental Sustainability, Vol. 5: 1-5, 2013.

[6] R. A. Matthew, M. Halle, J. Switzer (Eds.). Conserving the Peace: Resources, Livelihoods and Security. Winnipeg: International Institute for Sustainable Development, 2002

[7] C. Pahl-Wostl. A conceptual framework for analyzing adaptive capacity and multi-level learning processes in resource governance regimes. Global Environmental Change, Vol. 19, No. 3: 354-465, 2009

[8] A. Sen. Development: Which Way Now? In The Political Economy of Development and Underdevelopment, edited by K.P. Jameson, Wilber, C.K. pp.7-28, 1996

[9] R.F.E Mumba. Policy and Legal Framework on Co-Management of Forest Resources. In Community-Based Management of Miombo Woodlands in Malawi, edited by Mzoma, R., Mwabumba, L., and Chirwa, pp. 27-29, 1999.

[10] L. Mehta. Whose Scarcity? Whose property? The case of water in Western India. Land Use Policy, Vol. 24: 654- 663, 2007.

[11] P. Le Billon. The political ecology of war: natural resources and armed conflicts. Political Geography, Vol. 20: 561- 584, 2001.

[12] NSO (National Statistical Office). Malawi Population and Housing Census 2008. National Statistical Office of Malawi, Zomba, 2008.

[13] L. M. Rebelo, M. P. McCartney, M. C. Finlayson. The 
application of geospatial analyses to support an integrated study into the ecological character and sustainable use of Lake Chilwa. Journal of Great Lakes Research, Vol. 37:83-92, 2011.

[14] N. Lancaster. The changes in the lake level. In Lake Chilwa studies of change in a tropical ecosystem edited by M. Kalk, A. J. McLachlan C. Howard-Williams, pp. 41-58. The Hague-Boston-London: Dr. W. Junk Publishers, 1979.

[15] G. Walsham. Doing interpretive research. European Journal of Information Systems, Vol. 15: 320-330, 2006

[16] H. R. Bernard. Research Methods in Anthropology: Qualitative and Quantitative Approaches, Walnut Creek, Lanham, New York and Oxford, AltaMira Press, 2011.

[17] R. K. Yin. Case Study Research: Design and Methods, 2nd ed. Thousand Oaks, CA: Sage, 1994

[18] K. D. Schuijt. Economic valuation of the Lake Chilwa wetland. In State of the environment study No. 18: Lake Chilwa Wetland Project, Zomba, Malawi, 1999

[19] H. R. Mloza-Banda. Appraisal of the lake Chilwa Vegetation: Genesis and impact of burning of the marshes of Lake Chilwa in Southern Malawi. Bunda Journal of Agriculture, Environmental Science and Technology, Vol. 3: 13-27, 2005.

[20] GoM (Government of Malawi). Lake Chilwa wetland state of the environment, 2000.

[21] H. H. Kabwazi, J. G. M. Wilson. The Fishery of Lake Chilwa. In The Lake Chilwa Environment - a report of the 1996 Ramsar Site Study, edited by K. van Zegeren, M. Munyenyembe, Department of Biology, Chancellor College, Zomba, Malawi, 1998.

[22] R. Bhima. Subsistence use of water birds at Lake Chilwa, Malawi. In Water birds Around the World edited by C. Galbraith G. Boere, \& D. Stroud, Edinburgh: Stationery Office, pp. 244-256, 2006.

[23] J. Nagoli. Livelihoods analysis report for the Lake Chilwa Basin. Lake Chilwa Basin Climate Change and Adaptation Program, Zomba, Malawi, 2010.

[24] F. J. Njaya. Governance challenges for the implementation of fisheries co-management: Experiences from Malawi. International Journal of the Commons, Vol. 1, No. 1: 123-139, 2007.

[25] F. J. Njaya, S. Donda, C. Béné. Analysis of Power in Fisheries Co-Management: Experiences from Malawi. Society \& Natural Resources, 2011.

[26] A. Agrawal. The Role of Local Institutions in Adaptation to Climate Change, Washington DC: The World Bank, 2008.

[27] A. M. Russell, T. Dobson, J. G. M. Wilson. Fisheries Management in Malawi: Patchwork of Traditional, Modern, and Post-modern Regimes Unfolds. American Fisheries Society Symposium, Vol. 62, 2008.

[28] L. C. Zulu. Neoliberalization, decentralization and community-based natural resources management in Malawi: The first sixteen years and looking ahead. Progress in Development Studies Vol. 12, No. 2\&3:193-212, 2012.
[29] D. Kayambazinthu, C. Kogelheide. Power relations and control over resources in Chimaliro Forest Reserve and neighboring Village Forest Areas. German Association (DFG), 2001.

[30] Malawi National Archives. A letter from Game Warden in Lilongwe to the Honorable Chief Secretary dated 23/1/1930

[31] M. D. Kalanda-Sabola, E. M. T. Henry, E. Kayambazinthu, J. Wilson. Use of indigenous knowledge and traditional practices in fisheries management: a case of Chisi Island, Lake Chilwa, Zomba. Malawi Journal of Science and Technology Vol. 8: 9-29, 2007.

[32] A. Chilivumbo. The Fishermen of Lake Chilwa: A study in Adaptability. Paper presented at the International Biological Program Conference on Human biology and environmental change, Blantyre, Malawi, 1971.

[33] J. Pierre, B. G. Peters. Governance, politics and the state. London: Macmillan, 2000.

[34] Ramsar Convention Bureau. The Ramsar Convention Manual. A guide to the Convention on Wetlands. Ramsar, Iran, 2nd Edition, Gland Switzerland, 1971.

[35] Government of Malawi. Malawi Environmental Management Act of 1996, Ministry of Environmental Affairs, Lilongwe, 1996

[36] Government of Malawi. National Fisheries Policy 2012 2017, Ministry of Agriculture and Food Security, 2012.

[37] Government of Malawi. National Water Policy. Ministry of Irrigation and Water Development, 2007

[38] Government of Malawi. Wildlife Policy. Department of National Parks and Wildlife, 2000

[39] B. Chinsinga, B. Mangani, P. Mvula. The Political Economy of Adaptation through Crop Diversification in Malawi. IDS Bulletin Vol. 42, No. 3: 110-117, 2011.

[40] F. J. Njaya. The Lake Chilwa Fishing Household Strategies in response to water level changes: migration, conflicts and co-management. Ph.D. Dissertation, University of the Western Cape, Republic of South Africa, 2009.

[41] B. D. Ratner, P. Cohen, B. Barman, K. Mam, J. Nagoli, E. H. Allison. Governance of aquatic agricultural systems: analyzing representation, power, and accountability. Ecology and Society, Vol. 18, No. 4: 59, 2013.

[42] United Nations Convention on the Law of the Sea, 1982

[43] J. P. Hoffmann. A Contextual Analysis of Differential Association, Social Control, and Strain Theories of Delinquency. Social Forces, 81 (3): 753-785, 2003.

[44] A. Giddens. The Constitution of Society: Outline of the Theory of Structuration. Berkeley and Los Angeles: University of California Press, 1984.

[45] W. H. Sewell. A Theory of Structure: Duality, Agency, and Transformation. The American Journal of Sociology, Vol. 98, No. 1, pp. 1-29, 1982.

[46] B. J. Risman. Gender as a Social Structure: Theory Wrestling with Activism. Gender and Society, Vol. 18, No. 4: 429-450, 2004. 